\title{
An Investigation Into The Coupling of Sloshing Effect Due to Translation Force of FLNG Motions
}

\author{
Luhut Tumpal Parulian Sinaga ${ }^{1}$, I Ketut Aria Pria Utama ${ }^{1}$, and Aries Sulisetyono ${ }^{1}$
}

\begin{abstract}
The motion of FPSO fluid inside gas carrier is normally restricted by loading condition of the vessel, whether the vessel is operated at near empty condition or under $30 \%$ from fully loaded condition. In this way, resonance or sloshing effects of the fluid on the FPSO's hull are limited. However, nowadays the FPSO carriers are considered to be operated at intermediate loading condition and also during the production. In this condition, the FPSO is more likely to be induced into resonance due to wave action and FPSO motion. This resonance or sloshing behavior of the FPSO leads to high impact pressure on hull storage construction. A theory based on gas dynamics for shock wave in a gas flow has been used to describe the motion of the fluid. Then, a linier potential theory as used in strip theory ship motion. The current paper describes a study model experiment in Maneuvering \& Ocean Engineering Basin (M.O.B) at the Indonesian Hydrodynamic Laboratorium. It uses a wooden barge at scale of $1: 70$, together with various wave heading, amplitude and period. Using high speed video camera, the wave front formed by the bore of the FPSO in resonance is observed and the impact to the tank hull is measured.
\end{abstract}

Keywords $\longrightarrow$ non- linier hydrodynamic, sloshing, impact, motion

Abstrak-Gerakan FPSO cairan di dalam pembawa gas LNG biasanya dibatasi oleh kondisi pemuatan kapal, apakah kapal tersebut dioperasikan pada kondisi muatan mendekati kosong atau di bawah $30 \%$ dari kondisi muatan penuh. Dengan cara ini, resonansi atau efek permukaan bebas cairan di konstruksi lambung FPSO terbatas. Namun, pada penelitian saat ini FPSO di operasikan pada kondisi pembebanan menengah. Dalam kondisi ini , FPSO adalah lebih mungkin diinduksi ke resonansi dari akibat karena gelombang menerpa lambung kapal dan gerakan FPSO itu sendiri. Resonansi ini atau pengaruh permukaan bebas muatan gas atau cairan di ruang muat menyebabkan dampak tekanan yang tinggi pada konstruksi lambung kapal FPSO. Sebuah teori yang didasarkan pada dinamika gas untuk gelombang kejut dalam aliran gas dapat digunakan untuk menggambarkan gerakan fluida. Kemudian, potensi teori linier seperti yang digunakan dalam teori olah gerak kapal. Pada penelitian ini menjelaskan percobaan uji model FPSO yang dilaksanakan pada kolam uji maneuvering ( MOB ) di Laboratorium Hidrodinamika Indonesia. Ini menggunakan model tongkang kayu di skala 1 : 70 , dengan berbagai variasi gelombang, amplitudo dan periode. Menggunakan kamera video berkecepatan tinggi, gerakan fluida yang terjadi pada ruang muat diamati dan direkam dengan menempatkan sebuah kamera pada bagian depan ruang muat fluida FPSO.

Kata Kunci_hidrodinamika non-linier, sloshing, tekanan, olah gerak

\section{INTRODUCTION}

$\mathrm{T}$ his study considers the motion responses of a FLNG in waves, coupled with sloshing in cargo. When a floating body with liquid cargo is under excitation in ocean wave, its FLNG motion is affected by both external wave excitation and internal sloshing-induced forces, moment and impact load on FLNG cargo structures. The former is an important task in the design of internal cargo structure. In particular, this is an essential element in the design of membrane-type liquefied natural gas (FLNG) carriers or FLNG platforms. The latter has been of interest for the prediction of translation dynamic forces behavior of ship motion. Meanwhile the design load of the main hull structure is governed by the external wave load and internal load due to ship motion, the sloshing impact load due to liquid motion inside the tank governs the

${ }^{1}$ Luhut Tumpal Parulian Sinaga, I Ketut Aria Pria Utama, and Aries Sulisetyono are with Departement of Naval Architecture and Shipbuilding Engineering, Faculty of marine Technology, Institut Teknologi Sepuluh Nopember, Surabaya, 60111, Indonesia. Email: luhuttps@yahoo.com.sg. design load for the FLNG containment system and surrounding bulkheads.

Many studies on the ship sloshing problem were carried out in 1970's and early 1980's for the design of FLNG carriers. Recently, the demand of sloshing analysis is rising again for the design of larger FLNG carriers and LNG Floating-Production-StorageOffloading (FPSO) vessels. Many numerical studies on sloshing flows have been reported during last two decades. Some representative works have been introduced by [1-6]. Despite numerous studies, not many methods are applicable for actual engineering use such as the simulation of violent flows and the prediction of impact loads. However, recent experimental and numerical study shows that even at the milder sea states, the sloshing load at the filling level near the $30 \%$ of tank height can be as high as the sloshing load at the high filling level at the North Atlantic [7-9]. This study aims to observed on the physical phenomena involved in violent sloshing flows, and the development of proper numerical models for practical use. Both the experimental observation and numerical computations were carried out [10-12]. The model experiment was studied presented on simplified model of heave and pitch motion of an FLNG due to sloshing effect and comparison some experiment results. This study aim to observed coupling effect from pitching and heaving to 
global of motion. The dynamic motion of an FLNG consist of rotation and translation called 6 degree of motion $[13,14]$.

\section{METHOD}

\section{A. Model Set-Up and Its Particular}

The FLNG model was produced according to a scale 1 : 70 .The model consists of hull body (barge shape structure) completed with cargo tank, normal bilge tank. The FLNG model was made from wood and steel frame which is required strengthen the hull body with principle particular as set on Table 1. The model should be statically and dynamically balanced to adjust the position centre of gravity and radii gyration see Figures $1-2$. The Cargo tank is made of acrylic transparent glass $1 \mathrm{~cm}$ wall thickness. In the following lines plan and table of principal dimension of FLNG with scale factor.

The model test were carried out in regular and random waves. The random waves were adjusted to represent Pierson-Moskowitz wave spectrum. The waves in basin were generated by means of a wave generator.

\section{B. Notation \& Procedure of Calibration}

The notation of the motion and force components was taken in relation to their directions with respect to the model system of axes. The following notations and sign conventions are applicable in Table 3.

\section{Procedure Calibration}

All from the recorded decay curves of the various motion decay or free extinction tests natural periods have been derived to used for evaluated. The damping coefficients were derived from the decrease of motion amplitude for two successive oscillations as follows: (See Figure 3), and for calibration factor (see Figure 4).

$\phi(\mathrm{t}) \quad=$ time trace of motion $\phi$

$\phi \mathrm{n} \quad=$ motion amplitude of $\mathrm{n}$-th oscillation

$\mathrm{T} \phi \quad=$ natural period of motion $\phi$.

The logarithmic decrement $\Delta$ can be determined:

$\Delta=\ln \left(\phi \mathrm{n}_{1} / \phi \mathrm{n}_{2}\right)$

The dimensionless damping coefficient or damping ratio to critical damping is expressed by:

$\mathrm{k}=\mathrm{b} / \mathrm{b}_{\text {critical }}$

Which can be calculated from the logarithmic decrement by:

$\mathrm{k}=\Delta /\left(4 \pi^{2}+\Delta^{2}\right)^{1 / 2}$

Linear (Equivalent) Damping

When the system behaviors is almost linear (equivalent) damping can be derived as follows:

The linear motion $\mathrm{x}(\mathrm{t})$ during a free extinction test can be described by, assuming a linear system:

$$
\begin{aligned}
& (m+1) \cdot \frac{d^{2} x}{d t^{2}}+B_{x \cdot} \frac{d x}{d t}+C \cdot x=0 \\
& \left(I+I_{A}\right) \cdot \frac{d^{2} \phi}{d t^{2}}+B_{\phi} \cdot \frac{d \phi}{d t}+C_{\phi} \cdot \phi=0
\end{aligned}
$$

Where:

$\mathrm{m} \quad=$ vessel mass

I $\quad=$ vessel inertia for rotation

$\mathrm{A} \quad=$ added mass

$\mathrm{I}_{\mathrm{A}} \quad=$ added inertia for rotation

$\mathrm{B}_{\mathrm{x}} \quad=$ linear damping coefficient
$\mathrm{B}_{\phi} \quad=$ angular damping coefficient

$\mathrm{C}_{\mathrm{x}} \quad=$ linear spring coefficient

$\mathrm{C}_{\phi} \quad=$ angular spring coefficient

The spring coefficients are a combination of the hydrostatic spring and the stiffness of the mooring system.

The non-damped natural period of this system can be calculated as:

$T_{\phi}=2 \pi \sqrt{\frac{I+I_{A}}{C_{\phi}}}$
$T_{x}=2 \pi \sqrt{\frac{m+A}{C_{x}}}$

For such a system the critical damping $\mathrm{B}_{\text {crit }}$ is defined as:

$B_{x_{\text {crit }}}=2 \sqrt{(m+A) \cdot C_{x}}$

$B_{\phi_{c i t}}=2 \sqrt{\left(I+I_{A}\right) \cdot C_{x}}$

If the damping is equal to, or larger than, the critical damping, no overshoot of dynamic amplification occurs in the system. To determine the degree of damping in a system, the damping is sometimes expressed as a ratio $\mathrm{B}_{\beta}$ of the linear damping coefficient $\mathrm{B}$ and the critical damping $\mathrm{B}_{\text {crit }}$ :

$B_{\beta}=\frac{B}{B_{\text {crit }}}$

\section{RESULT AND ANALYSIS}

The prediction of responses structure of an FLNG is generally made in regular wave. In currently work various heading angle $(90,135)$ degree, wave height $2 \mathrm{~m}$ and filling of the storage tank $30 \%$, period (see Table 2 test with regular wave) and for simplicity analysis purpose using mark point " " and " " ( for heading angle $90 \mathrm{deg}$ and for heading angle $135 \mathrm{deg}$ ). In this model test sort term response calculation of linier non linier are given natural Response Amplitude Operator (RAO) of FLNG (see Table 3). Based on linier theory it is assumed that for each wave period the relation between input wave amplitude and motion always the same. From the test were carried out rotation moment and translation forces .Specially for rotation moment was discussed in [14]. The translation forces at heading seas 90 degrees and 135 degrees (See Figures 5, 6 and 7). The result are for RAO of Surge many different specially for wave frequency $0.35 \mathrm{rad} / \mathrm{sec}$, for RAO of Sway motion at heading seas 135 degree and heading seas 90 degree, there is significant wave amplitude at frequency 0.35 $\mathrm{rad} / \mathrm{sec}$ and for heading 90 degree mostly RAO trend curve is attributed (See Figure 6) and for RAO of heaving heading seas 90 degree was much higher then heading seas 135 degree because of the damping show a tendency increase (See Figure 7). When the wave spectrum is coming to hull construction of FLNG with wave direction are beam seas position as seen on Figure 8 is according to test program has set on Table 2, so that model has motion acculamutive with sloshing. The wave breaking and splashes are typeal phenomena observed in traslation dynamic forces caused to sloshing flow. Figure (9 a,b,c) shows three of snapshots of sloshing flow at 30 
$\%$ storage tank filling. A typical process of impact at 30 $\%$ filling condition is (1) formation of strongly non linier free surface flow, (2) impact on side wall, and (3) wave run-up along wall and splashes generation. It is doubt that splashes provide a significant contribution to impact or global motion. Our experiment observation shows that splashes provide contribution impact occurrence of about $\mathrm{P}=5 \mathrm{Kg}$ on Figure 9a.

\section{CONCLUSION}

In the present study, the physical and technical issues of sloshing flows in FLNG ship are described. The physical phenomena in violent sloshing flows have been carefully observed in experiments, which was carried out at IHL Surabaya. Based on the present study, the following conclusions are drawn:

1. The coupled motion rotation moment and translation forces problem is well predicted by the linear theory based on the impulsive response function must be continued with mathematical modeling to validated and solve the instrumentation error. Specially for motion induced by sloshing dynamic.

2. There are several physical issues which should be considered in sloshing analysis. These issues include the effects of cushioning due to air pocket, local wave breaking, splashes and pressure to hull construction. .To understand their effects is critical to develop numerical models for sloshing analysis is need to study more detail.

3. The nonlinearity of sloshing flow plays a critical role in the ship motion coupled with sloshing. The sloshing-induced translation force is not linearly proportional to excitation amplitude. Therefore, the ship motion coupled with sloshing does not vary in a linear manner with respect to wave amplitude.

\section{ACKNOWLEDGEMENT}

The authors wish to tanks the Indonesia Hydrodynamic Laboratory (IHL) staff to provide the experimental data of the current paper.

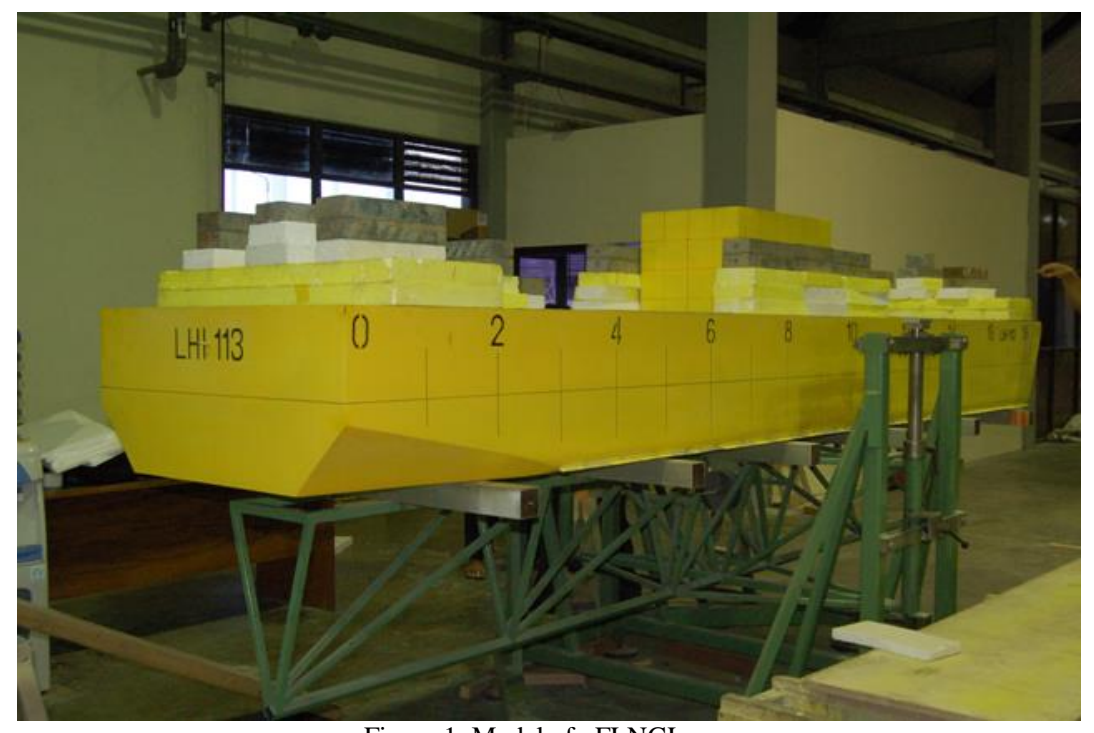

Figure 1. Model of FLNGL

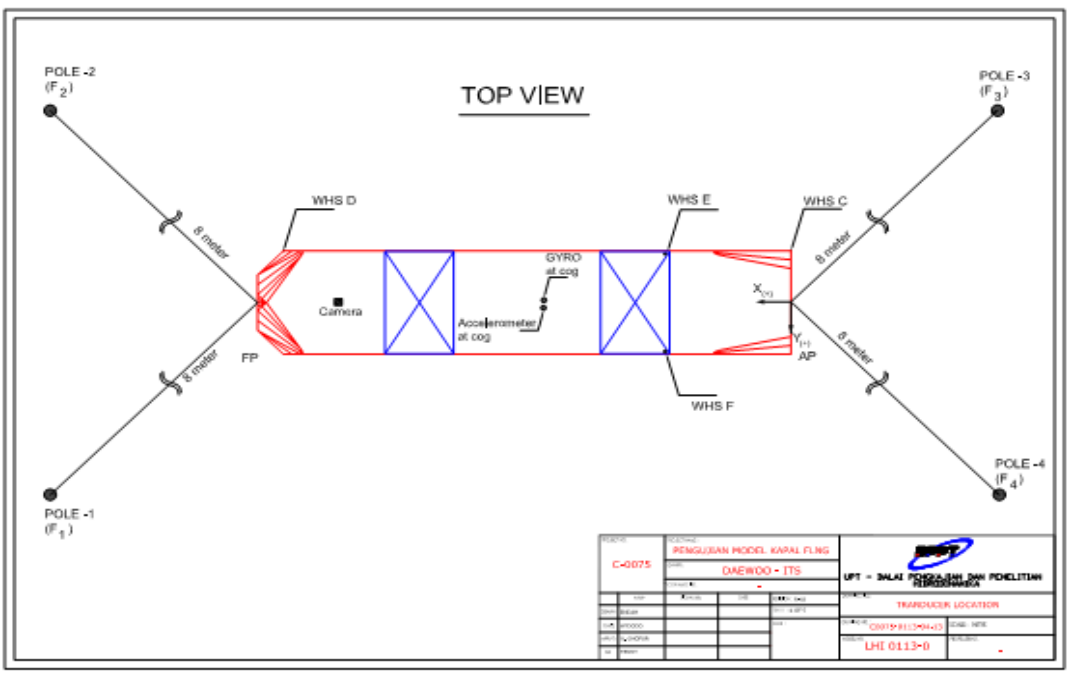

Figure 2. Set up position of model FLNG in model basin 


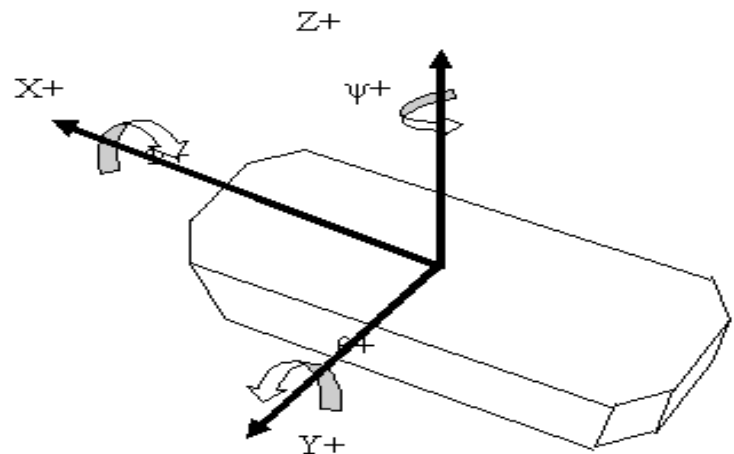

Figure 3. Model-fixed system of axes [14]

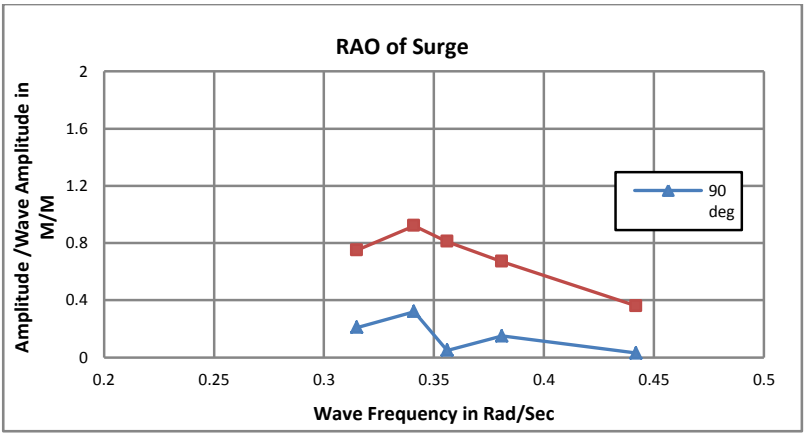

Figure 5. RAO of surge at $90 \mathrm{deg}$ and $135 \mathrm{deg}$

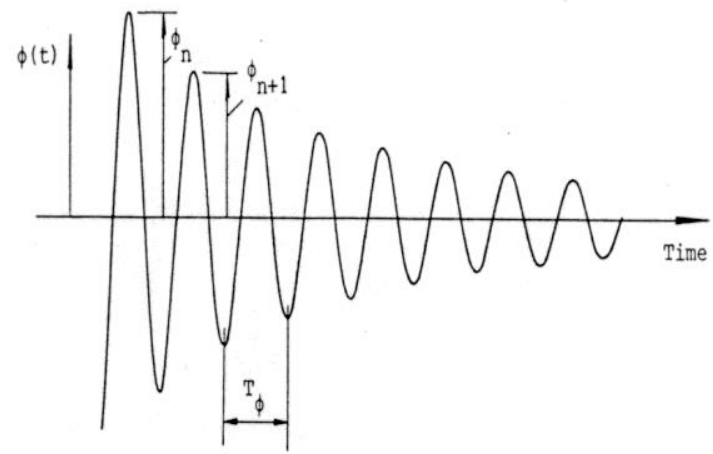

Figure 4. Decay test [15]

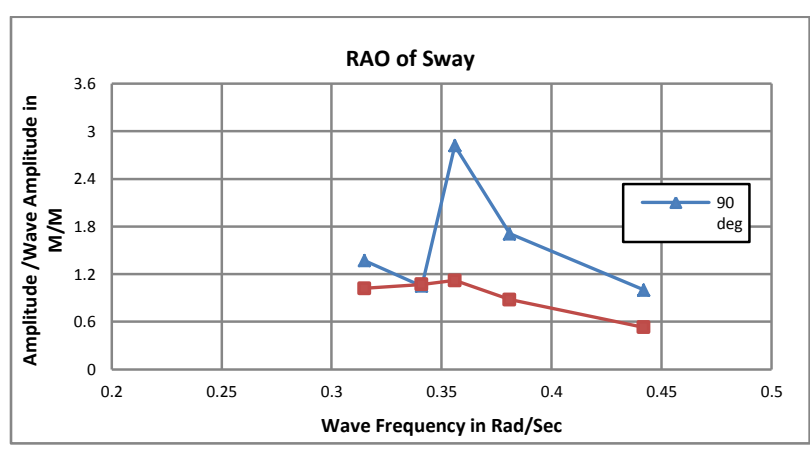

Figure 6. RAO of sway at $90 \mathrm{deg}$ and $135 \mathrm{deg}$

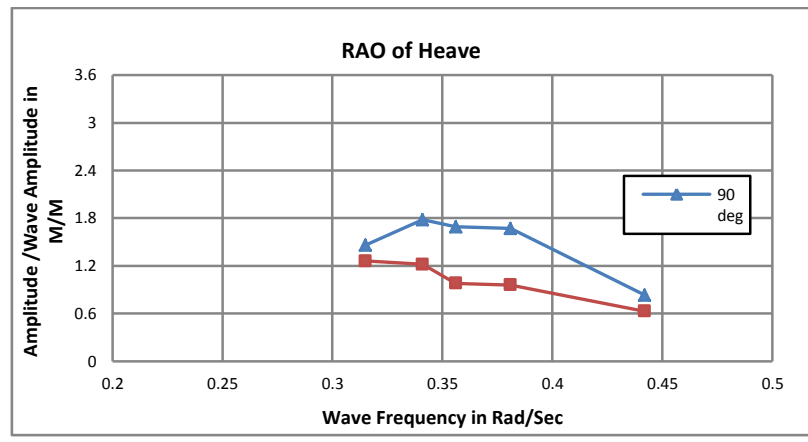

Figure 7. RAO of heave at $90 \mathrm{deg}$ and $135 \mathrm{deg}$

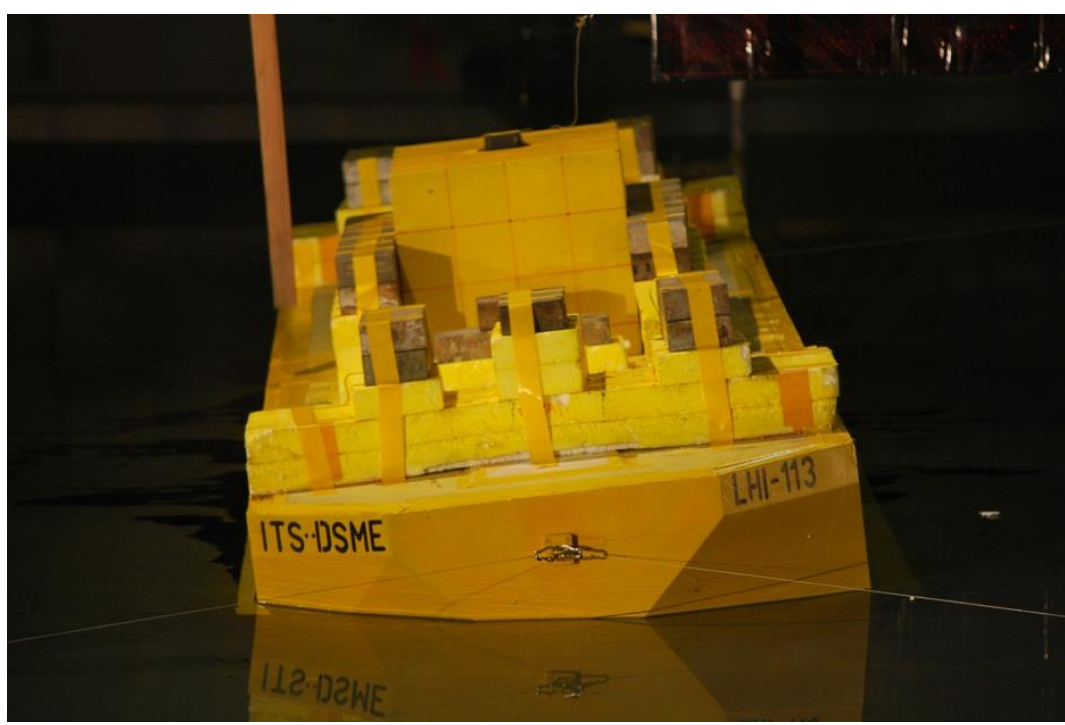

Figure 8. Motion of the model FLNG 


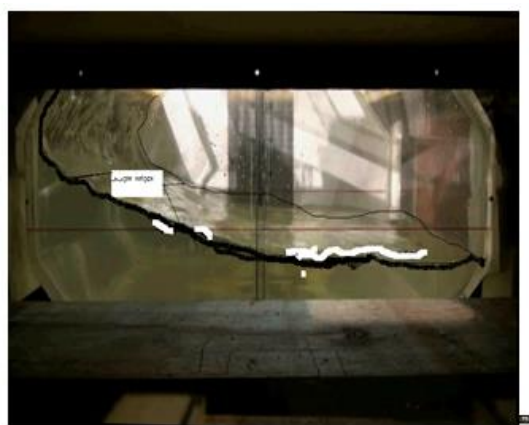

(a)

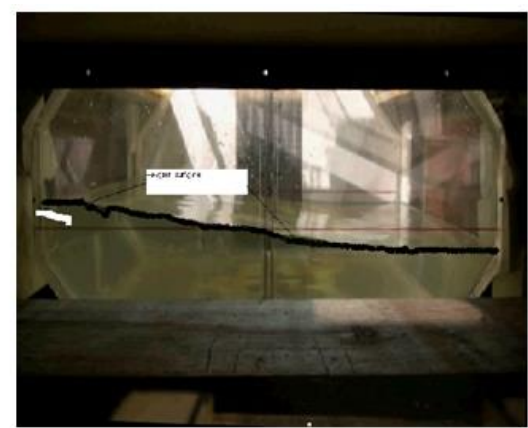

(b)

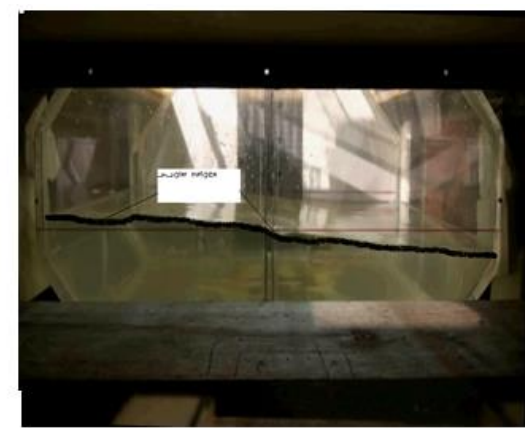

(c)

Figure 9. Splashes after side impact occurrence at model $30 \%$ storage filling tank

TABLE 1.

PRINCIPAL PARTICULAR

\begin{tabular}{|c|c|c|c|c|c|}
\hline Description & Symbol & Full Scale & & Model of Sc & \\
\hline Length Overall & LOA & 350 & $\mathrm{~m}$ & 500 & $\mathrm{~cm}$ \\
\hline Length Between Perpendiculars & LPP & 330 & $\mathrm{~m}$ & 442 & $\mathrm{~cm}$ \\
\hline breadth mid ship section & B & 66 & $\mathrm{~m}$ & 92,86 & $\mathrm{~cm}$ \\
\hline Depth & $\mathrm{D}$ & 27.30 & $\mathrm{~m}$ & 39,66 & $\mathrm{~cm}$ \\
\hline Draft & $\mathrm{T}$ & 13.200 & $\mathrm{~m}$ & 19,71 & $\mathrm{~cm}$ \\
\hline Displacement & Displ & 71.260 .600 & $\mathrm{Kg}$ & 77156 & $\mathrm{Kg}$ \\
\hline Length Centre of Grafity from AP & LCG & 150583 & $\mathrm{~m}$ & 215,32 & $\mathrm{~cm}$ \\
\hline Centre of Gravity from Keel & LCG & 21.800 & $\mathrm{~m}$ & 31,14 & $\mathrm{~cm}$ \\
\hline Length Centre of Bouyancy from AP & LCB & 180.585 & $\mathrm{~m}$ & 215,12 & $\mathrm{~cm}$ \\
\hline Vertical Centre of Bouyancy & $\mathrm{KB}$ & 6.999 & $\mathrm{~m}$ & 10,00 & $\mathrm{~cm}$ \\
\hline BM Trans & $\mathrm{BMv}$ & 26.745 & $\mathrm{~m}$ & 36,78 & $\mathrm{~cm}$ \\
\hline BM Long & BM1 & 571.173 & $\mathrm{~m}$ & 81,596 & $\mathrm{~cm}$ \\
\hline Roll Radius of Gyration & $\mathrm{Kxx}$ & 24.850 & $\mathrm{~m}$ & 34,36 & $\mathrm{~cm}$ \\
\hline Pitch Radius of Gyration & Kyy & 74.400 & $\mathrm{~m}$ & 106,29 & $\mathrm{~cm}$ \\
\hline Keel to Meta Centric & $\mathrm{Km}$ & 32.745 & $\mathrm{~m}$ & 46,76 & $\mathrm{~cm}$ \\
\hline Transverse GM & GMt & 10.945 & $\mathrm{~m}$ & 15,64 & $\mathrm{~cm}$ \\
\hline Calculation Roll Natural Period & Troll & 17.300 & $\mathrm{~m}$ & 2,07 & $\mathrm{~cm}$ \\
\hline
\end{tabular}

TABLE 2.

TESTS WITH REgulaR WAVE

\begin{tabular}{|c|c|c|c|c|c|c|}
\hline No & Filling of Level (\%) & Bilge Keel Type & Heading (deg) & AMPLITUDE (m) & Period (s) & NUM of Ocillation \\
\hline 1 & 30 & Normal & 90 & 2 & 14.5 & 15 \\
\hline 2 & 30 & Normal & 90 & 2 & 16.3 & 15 \\
\hline 3 & 30 & Normal & 90 & 2 & 17.3 & 15 \\
\hline 4 & 30 & Normal & 90 & 2 & 18.3 & 15 \\
\hline 5 & 30 & Normal & 90 & 2 & 19.0 & 15 \\
\hline 6 & 30 & Normal & 135 & 2 & 14.5 & 15 \\
\hline 7 & 30 & Normal & 135 & 2 & 16.3 & 15 \\
\hline 8 & 30 & Normal & 135 & 2 & 17.3 & 15 \\
\hline 9 & 30 & Normal & 135 & 2 & 18.3 & 15 \\
\hline 10 & 30 & Normal & 135 & 2 & 19.0 & 15 \\
\hline
\end{tabular}

TABLE 3.

NOTIFICATION 


\begin{tabular}{ccccc}
\hline $\mathrm{x}$ & : surge in $\mathrm{x}$-direction, & $\phi$ & $:$ & roll about $\mathrm{x}$-axis, \\
$\mathrm{y}$ & $:$ sway in y-direction, & $\theta$ & $:$ & pitch about $\mathrm{y}$-axis, \\
$\mathrm{z}$ & $:$ heave in z-direction & $\psi$ & $:$ & yaw about z-axis \\
\hline
\end{tabular}

\section{REFERENCES}

[1] O.M. Faltinsen, "A numerical non-linear method of sloshing in tanks with two-dimensional flow," J Ship Research 18, pp. 224$241,1978$.

[2] O.M. Faltinsen and O.F. Rognebakke, "Sloshing, Int. Conf. on Ship and Shipping Research," NAV. Venice: Italy, 2000.

[3] T.J. Bridges, "A numerical simulation of large amplitude sloshing," Proc. of the $3^{\text {rd }}$ Int. Numerical Ship Hydrodynamics, Paris, France, 1982.

[4] N.E. Mikelis, "Sloshing in partially filled liquid tanks and its effect on ship motions: Numerical simulations and experimental verification. RINA Spring meeting, London, 1984.

[5] G.X. Wu, Q.M. Ma, and R. Eatock-Taylor, "Numerical simulation of sloshing waves in a 3D tank based on a finite element method," Applied Ocean Research 20, 1998, pp. 337355 .

[6] Y. Kim, "Numerical simulation of sloshing flows with impact load," Applied Ocean Research 23, 2001, pp. 53-62.

[7] Y. Kim, Y.S. Shin, and K.H. Lee, "Numerical study on sloshinduced impact pressures on three-dimensional prismatic tanks," Applied Ocean Research 26, 2004, pp. 213-226.

[8] J.J. Monaghan, "Simulating Free Surface Flows with SPH," Jour Computational Physics 110, pp. 399-406, 1994.
[9] J. Dillingham, "Motion studies of a vessel with water on deck," Marine Technology 18,1981.

[10] Y. Kim, "A numerical study on sloshing flows coupled with ship motion-the anti-rolling tank problem," Journal of Ship Research 46, pp. 52-62. 2002

[11] O.F. Rognebakke, and O.M. Faltinsen, "Coupling of sloshing and ship motions," Jour Ship Research 47, pp. 208-221. 2003.

[12] Final Report No: IHL-BPPT/C073/IX/2010, J. 2010 IHL model test no: 0113 FLNG Vessel.

[13] L.T.P. Sinaga, I.K.A.P. Utama, and A. Sulissetyono, "Simplified model of heave and pitch motion of an FLNG due to sloshing effect and comparison some experiment results," Proceeding of the $13^{\text {th }}$ International conference on QIR013, Jokjakarta, 2013.

[14] L.T.P. Sinaga, I.K.A.P Utama., and A. Sulisetyono., "An investigation in to coupling of sloshing, effect on a FLNG motion," Proceeding of the $5^{\text {th }}$ international conference on technology and operation of offshore support vessel, (OSV) Singapore, 2013.

[15] L.T.P. Sinaga, I.K.A.P Utama., and A. Sulisetyono., "Experimental and Numerical Invertigation Into Sloshing Effect Due to Coupled Heave and Pitch Motion of FLNG Vessel," on IJTR,USA, 2014 